\title{
Monocyte to HDL Cholesterol Ratio and its association with cardio-metabolic risk factors in Primary Hyperparathyroidism
}

\section{Primer Hiperparatiroidili hastalarda monosit sayısının HDL Kolesterole oranı ve bu oranın kardiyo-metabolik risk faktörleri ile ilişkisi}

\author{
Muhammed KIZILGÜL ${ }^{1}$, Mustafa ÇALIŞKAN ${ }^{1}$, Bekir UÇAN ${ }^{1}$, Selvihan BEYSEL ${ }^{1}$, Mümtaz TAKIR ${ }^{2}$, Erkam SENCAR ${ }^{1}$, \\ Davut SAKIZ ${ }^{1}$, Erman ÇAKAL ${ }^{1}$, Mustafa ÖZBEK ${ }^{1}$
}

\begin{abstract}
The monocyte count to HDL-Cholesterol ratio (MHR) has been shown as a novel prognostic indicator of cardiovascular diseases. Several studies demonstrated that even mild primary hyperparathyroidism (PHPT) has an increased risk for cardiovascular disease. We aimed to evaluate MHR and its relation with cardiometabolic risk factors in patients with PHPT. Seventy-five patients with PHPT and 96 control subjects were included in the study. Demographic, anthropometric, and biochemistry results were recorded. The groups were compared in terms of monocyte counts, HDL-cholesterol (HDL-C), and MHR values. Correlation analysis was used to determine the relation between MHR and cardio-metabolic parameters. The mean age was similar in each group (52.69 \pm 10.91 to $53.33 \pm 7.70$ years, $p=0.667)$. Sex distribution and body mass index were similar in each group ( $p>0.05)$. Monocyte counts and HDL-C levels were similar in each group (479.73 \pm 136.97 vs $500.13 \pm 144.06$ and $51.54 \pm 11.99$ vs $51.95 \pm 11.66 \mathrm{mg} / \mathrm{dL}, p>0.05)$. MHR was similar between groups (9.71 \pm 3.65 vs $10.11 \pm 3.86, p>0.05)$. MHR was positively correlated with systolic blood pressure (SBP) and homeostasis model assessment of insulin resistance (HOMA-IR) $\left(r^{2}=0.276, p=0.019\right.$ and $r^{2}=0.271, p=0.020$, respectively). There was no association between MHR and other cardio-metabolic risk factors including diastolic blood pressure (DBP), carotid intima media thickness $(C I M T)$, and c-reactive protein (CRP) ( $p>0.05)$. The MHR did not increase in patients with PHPT. The MHR was correlated with SBP and HOMA-IR; however, it was not associated with other cardiometabolic risk factors including DBP, CIMT, and CRP.
\end{abstract}

Keywords: Primary hyperparathyroidism, cardio-metabolic risk factors, monocyte count to HDL-C ratio INTRODUCTION

Primary hyperparathyroidism (PHPT) is described öz

Monosit sayısının HDL-Kolesterole oranı (MHO)'nın yeni bir kardiyovasküler belirteç olduğu gösterilmiştir. Çoğu çalışmada, hafif primer hiperparatiroidi (PHPT)'nin bile kardiyovasküler hastaık riskini arttırdığı bildirilmiştir. Bu çalışmada, MHO'nun PHPT hastalarında yüksek olup olmadığını ve kardiyo-metabolik risk faktörleri ile ilişkisini değerlendirmeyi amaçladık. Çalışmaya primer hiperparatiroidisi olan 75 hasta ve 96 kontrol olgusu alındı. Demografik, antropometrik ve biyokimyasal veriler kaydedildi. Gruplar, monosit sayıları, HDL-Kolesterol (HDL-K) ve MHO'na göre karşılaştırıldı. MHO ile laboratuvar ve kardiyo-metabolik risk faktörleri arasındaki ilişki korrelasyon analizi ile değerlendirildi. Ortalama yaş her iki grupta benzerdi $(52,69 \pm 10,91$ 'e

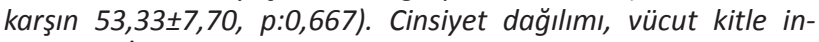
deksi (VKi) gruplar arası benzerdi $(p>0,05)$. Monosit sayısı ve HDL-K düzeyleri gruplar arası benzerdi $(479,73 \pm 136,97$ ye karşın

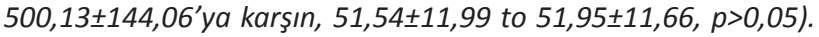
MHO gruplar arası benzerdi $(9,71 \pm 3,65$ 'e karşın, 10,11 $\pm 3,86$, $p>0,05)$. MHO sistolik kan basıncı ve insulin direnci (HOMA-IR) ile pozitif korrele idi $\left(r^{2}: 0,276, p: 0,019\right.$ ve $\left.r^{2}: 0,271, p: 0,020\right)$. MHO ile diğer kardiyovasküler risk faktörleri olan diastolik kan basıncı, karotis intima media kalınlığı (KIMK) ve c-reaktif protein (CRP) arasında korrelasyon saptanmadı $(p>0,05)$. Monosit sayısının HDL-Kolesterole oranı primer hiperparatiroidili hastalarda yüksek değildi. Monosit sayısının HDL-Kolesterole oranı sistolik kan basıncı ve insülin direnci ile korrele iken, diğer kardiyovasküler risk faktörleri olan diastolik kan basıncI, KIMK ve CRP ile korrele değildi.

Anahtar kelimeler: Primer hiperparatiroidi, monosit sayısının HDL-Kolesterole oranı, kardiyo-metabolik risk faktörleri

Received: 16.03 .2018

Accepted: 13.04 .2018

${ }^{1}$ Department of Endocrinology and Metabolism, University of Health Sciences, Diskapi Yıldırım Beyazıt Training and Research Hospital, Ankara, Turkey

2Department of Endocrinology and Metabolism, Medeniyet University, Goztepe Training and Research Hospital, Istanbul, Turkey

Yazışma adresi: Muhammed Kızılgül, Department of Endocrinology and Metabolism, University of Health Sciences, Diskapi Yıldırım Beyazıt Training and Research Hospital, Ankara, Turkey

e-mail: muhammedkzgl@gmail.com 
tests have come into use ${ }^{2}$.

Monocytes, as a source of several cytokines, directly affect platelets and endothelial cells, which induces proinflammatory and prothrombotic pathways ${ }^{3}$. Monocytes accumulate in lipids and differentiate into macrophages, which release metalloproteinases including elastase and collagenase, thereby causing atherosclerosis ${ }^{4}$. However, high-density lipoprotein cholesterol (HDL-C) interferes with the effects of monocytes, which decreases the risk of cardiovascular diseases (CVD) $)^{5,6}$. There is increasing interest in describing novel prognostic markers to facilitate the categorization of patients who have a greater risk for CVD. The monocyte count to HDL-C ratio (MHR) was postulated as a novel marker of prognosis for the development of future $\mathrm{CVD}^{7,8}$. A growing body of evidence supports that even mild PHPT has an elevated risk for $\mathrm{CVD}^{9-13}$.

We investigated the MHR and its relation to cardiometabolic risk factors in patients with PHPT.

\section{MATERIAL and METHOD}

\section{Patient selection}

Seventy-five patients who were diagnosed as having PHPT at Diskapi Training and Research Hospital between 2012 and 2016 and 96 controls were included in the study. Local ethics committee approval (06.11.2017-42/14) from Diskapi Training and Research Hospital was obtained and all participants provided written informed consent before the study began. Patients with multiple endocrine neoplasias, parathyroid cancer, thyroid cancer, hyperparathyroidismjaw tumor syndrome, and patients on drugs that counteract with calcium and vitamin D metabolism were excluded from the study. Diagnosis PHPT was defied as persistent hypercalcemia with normal or non-suppressed PTH concentrations ${ }^{14}$.

\section{Clinical, biochemical and hormonal measurements}

Basal demographic data, clinical features, carotid intima media thickness (CIMT) measurements were recorded for all participants. Weight, height, circumferences of waist (WC), body mass index (BMI), and systolic and diastolic blood pressure (SDP and DBP, respectively) were measured. Fasting state biochemical and hormonal measurements were performed in the morning using colorimetric methods and complete blood counts were obtained from all participants. An intact chemiluminescent immunoassay of PTH (Immulite 2000) was used to measure serum PTH levels. 25-OH vitamin D concentrations were measured using a radioimmune assay.

High-resolution B-mode ultrasound (EUB 7000 HV; Hitachi, Tokyo, Japan) with a 13-MHz linear array transducer was used to image parathyroids. Carotid intima-media thickness (CIMT) was measured to assess carotid atherosclerosis. In healthy middle-aged individuals, CIMT between 0.6 and $0.7 \mathrm{~mm}$ is accepted as normal, however, CIMT of $\geq 1 \mathrm{~mm}$ is associated with higher risk for CVD ${ }^{15}$. CIMT was measured by a B-mode imaging high-resolution ultrasound (EUB $7000 \mathrm{HV}$; Hitachi, Tokyo, Japan). CIMT was described as the distance between the blood-intima and media-adventitia boundaries on B-mode imaging high-resolution ultrasound system. All ultrasonographic measurements were performed by the same investigator (MC).

\section{Statistical analysis}

All statistical analyses were performed by using the JMP 13.0.1 software (SAS Institute, Cary, NC, USA). Quantitative data are expressed as mean \pm standard deviation, or counts and proportions for categorical data. Normality of distribution was examined by using the Kolmogorov-Smirnov or Shapiro-Wilk W test. The chi-square or Fisher's exact test was used when variables are categorical. Student's t-test was used for normally distributed continuous variables and the Mann-Whitney $U$ test for those that did not fit normal distribution. Correlations were assessed using Pearson's and Spearman's correlation. A p value lower than 0.05 was accepted statistically significant. 


\section{RESULTS}

Seventy-five patients with PHPT and 96 controls were enrolled in the study. The mean age was similar in both groups $(52.69 \pm 10.91$ vs $53.33 \pm 7.70$ years, $\mathrm{p}=0.667)$. Sex distribution and BMI was similar in each group ( $p=0.081$ and $p=0.159$, respectively). White blood cell count, vitamin $D$, fasting plasma glucose, creatinine, HDL-C, LDL-C, triglyceride and $\mathrm{C}$-reactive protein (CRP) levels were similar between the groups. SBP and DBP, calcium, and parathormone levels were higher in the PHPT group $(p<0.0001)$. Phosphorous levels were significantly lower in the PHPT group $(p<0.0001)$. CIMT and HOMA-IR were increased in the PHPT group $(p<0.05)$. Monocyte counts and HDL-C levels were similar in both groups $(479.73 \pm 136.97$ vs $500.13 \pm 144.06, p=0.374$ and $51.54 \pm 11.99$ vs $51.95 \pm 11.66, p=0.825$ ) (Table 1 ).

The MHR was similar in both groups $(9.71 \pm 3.65$ vs 10.11 $\pm 3.86, p=0.506)$. MHR and SBP and HOMA-IR were positively correlated $\left(r^{2}=0.276, p=0.019\right.$ and $\left.r^{2}=0.271, p=0.020\right)$. The MHR was not related to ot- her cardio-metabolic risk factors including DBP, CIMT and CRP (Table 2).

Table 2. The correlation between monocyte/HDL ratio and clinical, biochemical and hormonal parameters in the PHPT group.

\begin{tabular}{lll}
\hline & $\mathbf{R}^{\mathbf{2}}$ & $\mathbf{p}$ \\
\hline Systolic blood pressure & 0.276 & 0.019 \\
Diastolic blood pressure & 0.127 & 0.290 \\
Calcium & 0.201 & 0.084 \\
Phosphorous & 0.061 & 0.604 \\
Parathormone & 0.082 & 0.485 \\
Vitamin D & 0.063 & 0.590 \\
Fasting Plasma Glucose & -0.018 & 0.880 \\
LDL-cholesterol & -0.135 & 0.253 \\
HDL-cholesterol & -0.008 & 0.950 \\
BMI & 0.178 & 0.130 \\
CIMT & 0.118 & 0.314 \\
CRP & 0.024 & 0.839 \\
HOMA-IR & 0.271 & 0.020 \\
\end{tabular}

Abbreviations: $B M I=b o d y$ mass index; $C I M T=$ carotid intimamedia thickness; $C R P=C$-reactive protein; $H O M A-I R=$ homeostasis model assessment of insulin resistance

\section{DISCUSSION}

Our aim was to evaluate the correlation between

Table 1. Clinical and demographic characteristics of patients and controls.

\begin{tabular}{|c|c|c|c|c|c|}
\hline & \multicolumn{2}{|c|}{ PHPT Group (n=75) } & \multicolumn{2}{|c|}{ Control Group $(n=96)$} & \multirow[b]{2}{*}{$\mathbf{p}$} \\
\hline & Mean or $\mathbf{n}$ & SD or \% & Mean or $\mathbf{n}$ & SD or $\%$ & \\
\hline Age (years) & 52.69 & 10.91 & 53.33 & 7.70 & 0.667 \\
\hline Sex (Female) & 65 & 87 & 73 & 76 & 0.081 \\
\hline $\mathrm{BMI}\left(\mathrm{kg} / \mathrm{m}^{2}\right)$ & 30.61 & 5.12 & 29.55 & 4.34 & 0.159 \\
\hline Systolic blood pressure (mm Hg) & 136.56 & 15.10 & 121.72 & 10.57 & $<0.0001$ \\
\hline Diastolic blood pressure (mm Hg) & 83.81 & 7.46 & 78.76 & 5.56 & $<0.0001$ \\
\hline White blood cell count $\left(\times 10^{9} / \mu \mathrm{L}\right)$ & 6812.80 & 1774.60 & 7169.21 & 2074.27 & 0.237 \\
\hline Monocyte $\left(x 10^{9} / \mu \mathrm{l}\right)$ & 479.73 & 136.97 & 500.13 & 144.06 & 0.374 \\
\hline Monocyte/HDL ratio & 9.71 & 3.65 & 10.11 & 3.86 & 0.506 \\
\hline Calcium (mg/dl) & 11.11 & 0.81 & 9.37 & 0.38 & $<0.0001$ \\
\hline Phosphorous (mg/dl) & 2.68 & 0.43 & 3.44 & 0.50 & $<0.0001$ \\
\hline Parathormone $(\mathrm{pg} / \mathrm{mL})$ & 236.89 & 223.96 & 60.55 & 25.40 & $<0.0001$ \\
\hline Vitamin $D(\mathrm{ng} / \mathrm{mL})$ & 14.76 & 12.71 & 15.31 & 11.76 & 0.776 \\
\hline Fasting Plasma Glucose (mg/dL) & 90.59 & 8.79 & 88.27 & 8.11 & 0.079 \\
\hline Creatinine $(\mathrm{mg} / \mathrm{dl})$ & 0.76 & 0.20 & 0.90 & 1.00 & 0.191 \\
\hline HDL-Cholesterol (mg/dL) & 51.54 & 11.99 & 51.95 & 11.66 & 0.825 \\
\hline LDL-Cholesterol (mg/dL) & 123.93 & 32.18 & 119.25 & 24.04 & 0.299 \\
\hline Triglyceride (mg/dL) & 147.18 & 61.83 & 142.43 & 69.78 & 0.641 \\
\hline CIMT (cm) & 0.67 & 0.13 & 0.60 & 0.10 & 0.0009 \\
\hline CRP (mg/L) & 3.41 & 3.31 & 3.34 & 2.98 & 0.882 \\
\hline HOMA-IR & 2.93 & 1.87 & 2.20 & 1.35 & 0.005 \\
\hline
\end{tabular}

Abbreviations: $B M I=$ body mass index; $C I M T=$ carotid intima-media thickness; $C R P=C$-reactive protein; HOMA-IR=homeostasis model assessment of insulin resistance; $S D=$ standard deviation 
MHR and cardiovascular risk factors in PHPT patients. MHR was correlated with SBP and HOMA-IR; however, it was not correlated with other cardiometabolic risk factors including DBP, CRP, and CIMT. We believe that ours is the first to evaluate the relationship between the MHR and cardiovascular risk factors in PHPT.

Monocytes migrate into tissue macrophages in interaction with platelets and endothelium, which exacerbates inflammation ${ }^{4}$. The monocyte count was demonstrated to predict the premature occurrence of coronary events, and the activation of monocytes is a key process in the beginning of atherosclerosis ${ }^{16,17}$. HDL-C exhibits anti-inflammatory, antioxidant, and anti-platelet effects via several pathways, including contribution to the cholesterol outflow from macrophages, inhibition of endothelial adhesion protein expression, and encouraging reverse transport of oxidized molecules ${ }^{18}$. HDL-cholesterol inhibits monocyte activities and interrupts the transformation of monocytes to macrophages, which decreases inflammation ${ }^{5}$. As a consequence, combining measurements of HDL-C and monocyte counts as the MHR might represent the basic inflammatory process.

The significance of MHR in CVD risk estimation has been evaluated in several diseases. Kanbay et al. ${ }^{19}$ first showed that increased MHR might predict CVD in chronic renal failure. Canpolat et al. ${ }^{20}$ reported that pre-ablation MHR was related with recurrence of atrial fibrillation following catheter ablation using cryoballoon. Pre-procedural MHR was demonstrated to be related to slow coronary flow and serious in-hospital adverse cardiac events and mortality following angiographic intervention in ST-segment elevation myocardial infarction (STEMI) ${ }^{20,21}$. Cetin et al. ${ }^{8}$ found that MHR could predict stent thrombosis following angiographic intervention for STEMI. Bolayir et al. ${ }^{22}$ showed that an increased MHR independently predicted 30-day mortality in acute ischemic stroke. Cardiomyocytes, endothelial cells, and smooth muscle cells have PTH receptors ${ }^{23}$, and increased PTH has been associated with myocardial fibrosis, calcification, and hypertrophy ${ }^{24}$. Several studies showed that PHPT had increased cardiovascular events and mortality, many of which improved after parathyroidectomy ${ }^{9-13}$. Hypertension, hyperlipidemia, CIMT, CRP, and insulin resistance are all well-studied CVD risk factors ${ }^{25,26}$. Patients with PHPT have a higher risk for CVD and these patients have increased cardiovascular-related mortality ${ }^{27}$. Various risk factors for CVD have been shown in patients with PHPT, including hypertension, and elevated CIMT, insulin resistance, and $C R P^{28-31}$. In the light of this information, we aimed to investigate whether MHR could be related to cardio-metabolic risk factors in patients with PHPT. Monocyte count, HDL-C levels and MHR did not differ between groups. We found a correlation between MHR and SBP and HOMA-IR; however, $\mathrm{MHR}$ was not correlated with other cardio-metabolic risk factors.

Hypertension (HT) leads to tissue damage in the heart and vessels, asymptomatic atherosclerosis and additional organ dysfunction ${ }^{32}$. Aydin et al. ${ }^{33}$ demonstrated that MHR was associated with silent organ damage in HT. We observed that MHR and SBP were positively correlated, which might support the results of this study. Several studies showed that PHPT is associated with insulin resistance and increased incidence of prediabetes and diabetes ${ }^{34,35}$. We found a correlation between MHR and HOMA-IR, which might support these results.

The findings of our study might be explained by many of our patients possibly being in the early stage of the disease, which might explain why MHR does not represent an association with all cardio-metabolic risk factors. This constitutes a possible limitation of the study. As another limitation it was a single-center study with a small sample size.

In conclusion, the MHR did not increase in patients with PHPT. The MHR correlated with SBP and HOMAIR; however, it was not associated with other cardiometabolic risk factors including DBP, CIMT, and CRP. Our findings do not support the thesis of MHR as a potential marker of CVD in patients with PHPT. Nevertheless, its association with SBP and HOMA-IR 
might show the necessity for more comprehensive studies to enlighten this relation.

\section{REFERENCES}

1. Minisola S, Pepe J, Piemonte S, Cipriani C. The diagnosis and management of hypercalcaemia. BMJ. Jun 2;350. 2015;350:h2723. https://doi.org/10.1136/bmj.h2723

2. Bilezikian JP, Cusano NE, Khan AA, Liu J-M, Marcocci C, Bandeira F. Primary hyperparathyroidism. Nat Rev Dis Prim. 2016;2:16033. https://doi.org/10.1038/nrdp.2016.33

3. Ancuta P, Wang J, Gabuzda D. CD16+ monocytes produce IL-6, CCL2, and matrix metalloproteinase-9 upon interaction with CX3CL1-expressing endothelial cells. J Leukoc Biol. 2006;80(5):1156-64. https://doi.org/10.1189/jlb.0206125.1.

4. Takahashi K, Takeya M, Sakashita N. Multifunctional roles of macrophages in the development and progression of atherosclerosis in humans and experimental animals. Med Electron Microsc. 2002;35(4):179-203. https://doi.org/10.1007/s007950200023

5. Murphy AJ, Woollard KJ, Hoang A, Mukhamedova N, Stirzaker RA, McCormick SPA, et al. High-density lipoprotein reduces the human monocyte inflammatory response. Arterioscler Thromb Vasc Biol. 2008;28(11):2071-7. https://doi.org/10.1161/ATVBAHA.108.168690

6. Tardif J-C, Grégoire J, L'Allier PL, Ibrahim R, Lespérance J, Heinonen TM, et al. Effects of reconstituted high-density lipoprotein infusions on coronary atherosclerosis: a randomized controlled trial. JAMA. 2007;297(15):1675-82.

https://doi.org/10.1001/jama.297.15.jpc70004

7. Zhang Y, Li S, Guo Y-L, Wu N-Q, Zhu C-G, Gao Y, et al. Is monocyte to HDL ratio superior to monocyte count in predicting the cardiovascular outcomes: evidence from a large cohort of Chinese patients undergoing coronary angiography. Ann Med. 2016;48(5):305-12.

https://doi.org/10.3109/07853890.2016.1168935

8. Cetin MS, Ozcan Cetin EH, Kalender E, Aydin S, Topaloglu S, Kisacik HL, et al. Monocyte to HDL Cholesterol Ratio Predicts Coronary Artery Disease Severity and Future Major Cardiovascular Adverse Events in Acute Coronary Syndrome. Hear Lung Circ. 2016;25(11):1077-86.

https://doi.org/10.1016/j.hlc.2016.02.023

9. Smith JC, Page MD, John R, Wheeler MH, Cockcroft JR, ScanIon $\mathrm{MF}$, et al. Augmentation of central arterial pressure in mild primary hyperparathyroidism. J Clin Endocrinol Metab. 2000;85(10):3515-9.

https://doi.org/10.1210/jcem.85.10.6880

10. Yu N, Donnan PT, Flynn RW V, Murphy MJ, Smith D, Rudman $A$, et al. Increased mortality and morbidity in mild primary hyperparathyroid patients. the Parathyroid Epidemiology and Audit Research Study (PEARS). Clin Endocrinol (Oxf). 2010;73(1):30-4. https://doi.org/10.1111/j.1365-2265.2009.03766.x

11. Nilsson IL, Åberg J, Rastad J, Lind L, Clark OH, Perrier ND, et al. Circadian cardiac autonomic nerve dysfunction in primary hyperparathyroidism improves after parathyroidectomy. Surgery. 2003;134(6):1013-9; discussion 1019.

https://doi.org/10.1016/j.surg.2003.07.017

12. Piovesan A, Molineri N, Casasso F, Emmolo I, Ugliengo G, Ce- sario $F$, et al. Left ventricular hypertrophy in primary hyperparathyroidism. Effects of successful parathyroidectomy. Clin Endocrinol (Oxf). 1999;50(3):321-8. https://doi.org/10.1046/j.1365-2265.1999.00651.x

13. Stefenelli T, Abela C, Frank H, Koller-Strametz J, Globits S, Bergler-Klein J, et al. Cardiac abnormalities in patients with primary hyperparathyroidism: implications for follow-up. J Clin Endocrinol Metab. 1997;82(1):106-12. https://doi.org/10.1210/jcem.82.1.3666

14. Bilezikian JP, Potts JT, El-Hajj Fuleihan G, Kleerekoper M, Neer R, Peacock $M$, et al. Summary statement from a workshop on asymptomatic primary hyperparathyroidism: A perspective for the $21^{\text {st }}$ century. J Clin Endocrinol Metab. 2002;87(12):5353-61. https://doi.org/10.1210/jc.2002-021370

15. Jacoby DS, Mohler III ER, Rader DJ. Noninvasive atherosclerosis imaging for predicting cardiovascular events and assessing therapeutic interventions. Curr Atheroscler Rep. 2004;6(1):20-6. https://doi.org/10.1007/s11883-004-0112-8

16. Olivares $R$, Ducimetière $P$, Claude JR. Monocyte count: a risk factor for coronary heart disease? Am J Epidemiol [Internet]. 1993;137(1):49-53. Available from: http://www.ncbi.nlm. nih.gov/pubmed/8434572 https://doi.org/10.1093/oxfordjournals.aje.a116601

17. Gratchev A, Sobenin I, Orekhov A, Kzhyshkowska J. Monocytes as a diagnostic marker of cardiovascular diseases. Immunobiology. 2012;217(5):476-82. https://doi.org/10.1016/j.imbio.2012.01.008

18. Barter PJ, Baker PW, Rye K-A. Effect of high-density lipoproteins on the expression of adhesion molecules in endothelial cells. Curr Opin Lipidol. 2002;13(3):285-8.

https://doi.org/10.1097/00041433-200206000-00008

19. Kanbay M, Solak Y, Unal HU, Kurt YG, Gok M, Cetinkaya H, et al. Monocyte count/HDL cholesterol ratio and cardiovascular events in patients with chronic kidney disease. Int Urol Nephrol. 2014;46(8):1619-25. https://doi.org/10.1007/s11255-014-0730-1

20. Canpolat U, Aytemir K, Yorgun H, Şahiner L, Kaya EB, Çay S, et al. The role of preprocedural monocyte-to-high-density lipoprotein ratio in prediction of atrial fibrillation recurrence after cryoballoon-based catheter ablation. Europace. 2015;17(12):1807-15.

https://doi.org/10.1093/europace/euu291

21. Canpolat U, Çetin EH, Cetin S, Aydin S, Akboga MK, Yayla C, et al. Association of Monocyte-to-HDL Cholesterol Ratio with Slow Coronary Flow is Linked to Systemic Inflammation. Clin Appl Thromb. 2016;22(5):476-82. https://doi.org/10.1177/1076029615594002

22. Bolayir A, Gokce SF, Cigdem B, Bolayir HA, Yildiz OK, Bolayir $E$, et al. Monocyte/high-density lipoprotein ratio predicts the mortality in ischemic stroke patients. Neurol Neurochir Pol. 2017. pii: S0028-3843(17)30104-4. https://doi.org/10.1016/j.pjnns.2017.08.011

23. Schluter KD, Piper HM. Cardiovascular actions of parathyroid hormone and parathyroid hormone-related peptide. Cardiovasc Res. 1998;37(1):34-41. doi:S0008-6363(97)00194-6 [pii].

24. Fitzpatrick LA, Bilezikian JP, Silverberg SJ. Parathyroid hormone and the cardiovascular system. Curr Osteoporos Rep. 2008;6(2):77-83. https://doi.org/10.1007/s11914-008-0014-8

25. Akhabue E, Thiboutot J, Cheng J-W, Vittorio TJ, Christodoulidis G, Grady KM, et al. New and emerging risk factors for 
coronary heart disease. Am J Med Sci. 2014;347(2):151-8. https://doi.org/10.1097/MAJ.0b013e31828aab45

26. Cannon CP. Cardiovascular disease and modifiable cardiometabolic risk factors. Clin Cornerstone. 2007;8(3):11-28. Available from: https://www.ncbi.nlm.nih.gov/pubmed/18452839 https://doi.org/10.1016/S1098-3597(07)80025-1

27. Andersson P, Rydberg E, Willenheimer R. Primary hyperparathyroidism and heart disease--a review. Eur Hear J. 2004;25(20):1776-87. https://doi.org/10.1016/j.ehj.2004.07.010

28. Walker MD, Fleischer J, Rundek T, McMahon DJ, Homma S, Sacco R, et al. Carotid vascular abnormalities in primary hyperparathyroidism. J Clin Endocrinol Metab. 2009;94(10):384956. https://doi.org/10.1210/jc.2009-1086

29. Ljunghall S, Palmer M, Akerstrom G, Wide L. Diabetes mellitus, glucose tolerance and insulin response to glucose in patients with primary hyperparathyroidism before and after parathyroidectomy. Eur J Clin Invest [Internet]. 1983;13(5):373-7. Available from: http://www.ncbi.nlm.nih. gov/entrez/query.fcgi? $\mathrm{cmd}=$ Retrieve $\& \mathrm{db}=$ PubMed\&dopt $=\mathrm{Ci}$ tation\&list_uids $=6416850$ https://doi.org/10.1111/j.1365-2362.1983.tb00116.x

30. Almqvist EG, Bondeson A-G, Bondeson L, Svensson J. Increased markers of inflammation and endothelial dysfunction in patients with mild primary hyperparathyroidism. Scand J Clin Lab Invest. 2011;71(2):139-44. https://doi.org/10.3109/00365513.2010.543694

31. Luigi P, Chiara FM, Laura Z, Cristiano M, Giuseppina C, Luciano $C$, et al. Arterial hypertension, metabolic syndrome and subclinical cardiovascular organ damage in patients with asymptomatic primary hyperparathyroidism before and after parathyroidectomy: Preliminary results. Int J Endocrinol. 2012;2012:408295. https://doi.org/10.1155/2012/408295

32. Ojji DB, Libhaber E, Atherton JJ, Abdullahi B, Nwankwo A, Sliwa K. Risk-Factor Profile and Comorbidities in 2398 Patients With Newly Diagnosed Hypertension From the Abuja Heart Study. Medicine (Baltimore). 2015;94(39):e1660. https://doi.org/10.1097/MD.0000000000001660

33. Aydin E, Ates I, Fettah Arikan M, Yilmaz N, Dede F. The ratio of monocyte frequency to HDL cholesterol level as a predictor of asymptomatic organ damage in patients with primary hypertension. Hypertens Res. 2017;40(8):758-64. https://doi.org/10.1038/hr.2017.36

34. Procopio M, Magro G, Cesario F, Piovesan A, Pia A, Molineri $\mathrm{N}$, et al. The oral glucose tolerance test reveals a high frequency of both impaired glucose tolerance and undiagnosed Type 2 diabetes mellitus in primary hyperparathyroidism. Diabet Med [Internet]. 2002;19(11):958-61. Available from: http://www.ncbi.nlm.nih.gov/entrez/query.fcgi?cmd=Retrie ve\&db=PubMed\&dopt=Citation\&list_uids $=12421435$ https://doi.org/10.1046/j.1464-5491.2002.00809.x

35. Kumar S, Olukoga AO, Gordon C, Mawer EB, France M, Hosker JP, et al. Impaired glucose tolerance and insulin insensitivity in primary hyperparathyroidism. Clin Endocrinol. 1994;40(1):47-53. Available from: https://www.ncbi.nlm. nih.gov/pubmed/8306480

https://doi.org/10.1111/j.1365-2265.1994.tb02442.x 